Tarih Kültür ve Sanat Araştırmaları Dergisi

Revue des Recherches en Histoire Culture et Art مجلة البحوث التاريخية والثقافية و الفنية
Vol. 7, No. 4, November 2018

Copyright (C) Karabuk University http://kutaksam.karabuk.edu.tr

\title{
DOI: 10.7596/taksad.v7i4.1833
}

Citation: Epikhin, A., Zaytsev, O., Mishin, A., \& Mukhametshin, T. (2018). Contents and Value of a Judicial Parting Word by Juror Chairman in Modern Russian Criminal Trial. Journal of History Culture and Art Research, 7(4), 177-184. doi:http://dx.doi.org/10.7596/taksad.v7i4.1833

\section{Contents and Value of a Judicial Parting Word by Juror Chairman in Modern Russian Criminal Trial}

\author{
Alexander Epikhin¹, Oleg Zaytsev², \\ Andrey Mishin ${ }^{3}$, Timur Mukhametshin ${ }^{4}$
}

\begin{abstract}
Russian criminal proceedings undergo numerous changes aimed at criminal proceeding efficiency improvement. The differentiation of criminal justice includes the difference of criminal procedures. Some of them simplify, while others complicate the solution of guilt (innocence) issue. The consideration of a criminal case by a court with the participation of jurors is singled out among such complicated forms of criminal proceedings. The guilt or the innocence is determined by the jury in an advisory room after the study of the evidence brought by lawyers and prosecutors. Before the meeting of jurors takes place, the law establishes the procedure of a parting word announcement by a presiding judge (a professional judge leading the process). Such a judge announcement to a jury has special requirements set by Russian criminal law procedure, the violation of which may lead to the cancellation of the sentence. In addition, the article highlights the importance of ensuring the safety of all participants of the criminal process, including the jury. In the Russian criminalistics, the use of methods is associated traditionally with pre-trial proceedings on a criminal case. However, recently there has been some interest in forensic tactics development for a court session. In this paper, they showed the feature of trial forensic method use and the peculiarity of such development mastering.
\end{abstract}

Keywords: Jurymen, Parting word, Criminal case, Process, Legal proceedings, Presiding, Criminal justice, Security, Protection, Trial tactics.

\footnotetext{
${ }^{1}$ Doctor of laws, professor, Department of Criminal Process and Criminalistics, Kazan Federal University. E-mail: doc@epihin.ru

${ }^{2}$ Doctor of laws, professor, Institute of Legislation and Comparative Law under the Government of the Russian Federation. E-mail: oleg010663@mail.ru

${ }^{3} \mathrm{PhD}$ in Law, associate professor, Department of Criminal Process and Criminalistics, Kazan Federal University. E-mail: Andrey.Mishin@kpfu.ru

${ }^{4}$ Faculty of law, post-graduate student of the Department of criminal procedure and criminology. Kazan Federal University. E-mail: tamerlan_9@mail.ru
} 


\section{INTRODUCTION}

The legal regulation of a parting word from a presiding judge, addressed to the jury before they go to a meeting room for a discussion and pass a verdict, is a complex process, which is regulated by the article 340 of RF Criminal Procedure Code. We draw attention to the fact that the law allows for additional clarifications and the clarification of the issues posed to the jury (The Article 344 of RF Criminal Procedure Code). In this case, according to the decision of the jury, they return to the courtroom, and the foreman makes such a request to the presiding judge.

\section{METHODS}

This study implements the following research methods: observation; deduction and induction; the use of formal logic laws; comparative analysis; formally legal.

\section{RESULTS AND DISCUSSION}

The consideration of criminal cases by a court with the participation of jurors raises a sufficient number of problems concerning the application of criminal procedural provisions. In order to resolve them and bring judicial practice to its uniform application, the Plenum of RF Supreme Court adopted a relevant resolution [1]. In particular, the issues of the procedure and the content of the parting word of the presiding officer are presented in several points. Thus, for example, the Plenum recommends that the court pays the jury's attention to prohibit the conclusion of guilt in its parting word, if it is based on inadmissible evidence (par. 24); the judge's right to stop the trial participant's speech if he refers to inadmissible evidence and to explain to the jury that they should not take this information into account in their verdict (paragraph 25); on the possibility of clarifying or supplementing the issues in the questionnaire, taking into account the opinion of the trial participants, giving a short parting word and returning the jury to the advisory room (paragraph 32); the right of the presiding judge, taking into account the opinion of the parties, to supplement or clarify the questions to the jury with a subsequent brief parting word; when the judicial investigation is resumed, the debate is repeated and the defendant is given the last word before the jury returns to the advisory room (p.32).

For example, in the criminal case, the appellate instance recognized the return of jurors to the courtroom and their appeal to the chairman with a request for additional explanations on the issues raised as legal and not inconsistent with the law (Article 344 of RF Criminal Procedure Code). The request of the jury for additional investigation of the case circumstances was discussed during the court session with the participation of the parties. The defense party - Defendant Denisiewich and his lawyer did not object to the resumption of the judicial investigation. At that, the presiding judge's decision to resume the judicial investigation is in accordance with the provisions of Part 6, Art. 344 of RF Criminal Procedure Code (vol. 15, p.c. 88). The verdict under the Part 1 of the Art. 117 of RF Criminal Code for torturing; item "d" ch. 2, art. 105 of RF Criminal Code for murder, part 2, Art. 167 of RF Criminal Code for deliberate destruction of other people's property left unchanged [2].

The Plenum paid a special attention to the peculiarities of the parting word to the jury (paragraph 33 and 34). Thus, in particular, in paragraph 33 the courts are recommended to explain the content of the law to the jury, which softens the defendant's position about the actual circumstances of the case, which may exclude his responsibility for the crime that is imputed to him. At that, the Plenum recalls that a judge is prohibited to express his opinion on guilt (innocence) and his attitude to the evidence established in the judicial investigation. In addition, a presiding judge is obliged to clarify to the jury their opportunity in a parting word, during making the guilty verdict, to decide on the recognition of the defendant deserving leniency, as well as the procedure for a criminal punishment appointment in this case (Part 4, article 340 
of RF Criminal Procedure Code).

The scientific literature has typical shortcomings in the content of the chairman's parting speech, which led to the cancellation of the verdict on the basis of the jury verdict.

The provision of a proper order and the organization of the trial by a presiding officer is the key to the future fair decision concerning the criminal case on the basis of the jury verdict. At the same time, a special attention should be paid to safety provision of all trial participants, including jurors [2]. During the examination of one of the criminal cases in the Supreme Court of the Republic of Tatarstan with the participation of jurors, several persons with a deep criminal record appeared in an open court session held during the warm season. Sitting in the front row in shorts, they demonstrated the body parts (knees, shins) covered with "prison" tattoos to the jurors, thereby trying to influence them. Having assessed the situation as the violation of the court session order, the presiding judge removed the above-mentioned persons from the courtroom [3].

The possibility for the criminal trial parties to object to the contents of the chairman's parting word (Part 6, Article 340 of RF Criminal Procedure Code) is indicated in paragraph 34 of the Plenum Decision. In this regard, it is important to provide a detailed statement of the parting word in the record of the court session. This task is facilitated in the case of making an appeal of the judge to the jury in writing, and it is attached to the materials of the criminal case, which is noted in the record of the court session. The court board, refusing to satisfy the defense complaint, pointed out that the parties, in accordance with Part 6 of the Art. 340 of RF CPC, were given the opportunity to raise objections in connection with the content of the parting word of the presiding judge, based on the violation of objectivity and impartiality principle by her. At the same time, the defendant and his lawyer stated that they had no objection to the content of the parting word [4]. According to T. Vladykina's fair opinion "a presiding officer must have a clear formulation of the charge in the form supported by the prosecutor during the trial process" [5].

The meaning of the parting word is to accentuate the attention of the jury on the most important procedural points of the whole trial course. The law makes special demands to this appeal, which do not allow a professional judge to exert any influence on the jury decision. The guarantee of the impartiality and objectivity of the presiding officer is the right of the parties to objections, which are recorded in the record of the court session.

To establish the guarantees for the jury independence and to oppose any possible influence on them by anyone, the law establishes an immediate leaving of jurors to the discussion room for discussion and make a verdict.

The content and the requirements that are imposed on the parting word of the presiding officer is established in Part 3 of the Art. 340 of RF Criminal Procedure Code.

Let's consider in more detail each of the items specified in Part 3 of Art. 340 of Criminal Procedure Code. So, the presiding officer:

1) Gives the contents of the charge. The content of the charge, which is finally formulated by the public prosecutor, must be brought by the presiding officer in a form clear to the jury. In this regard, B. Kanevsky and A. Bosov point out correctly that "the principle of intelligibility is the guarantee of communicative success, it should be the main one in the speech behavior of all trial participants, at least in the presence of the jury. Practice shows that it is not always possible to be clear for a lawyer" [1]. Often in court practice, the wording of the charge is a list of episodes of criminal activity, indicating, for example, all organizations with their individual requisites, which ultimately complicates the perception of the information received by the jury. 
2) Informs the contents of the criminal law providing the responsibility for the commission of an act in which the defendant is accused. So, for example, the presiding judge did not explain to the jury that an assassination attempt can be committed with a direct intent only, when the guilty person wishes the death of another person. Despite the absence of objections to the parting word of the judge, the failure of the jury to explain this provision of the criminal law could affect the jury decision on Zhirnov's and Galyutin's guilt in Milyaev's attempted murder. With regard to them, the jury found proved only the blows by feet and hands to Milyaev without the agreement with Kiselev, who stabbed the victim [2].

3) Recalls the evidence examined in court, both of those which convict the defendant and of those which justify him, without expressing his attitude to these evidences and without drawing conclusions from them. Constructive criticism [1] is noted in the literature concerning the use of the word "recall" in this paragraph. In this context, the law indicates the duty of the judge to list the evidences that were examined during the court session and were recognized by the court as admissible.

4) Sets out the positions of the public prosecutor and defense. Such a statement should not be carried out with an accusatory or justifiable tone [2]. Thus, for example, the cassation instance established that the essence of the charge was set out by the public prosecutor in the opening statement and is correctly reflected in the question sheet, by which the jury was guided during the verdict. At the same time, since "Z" insisted that it received money not as a bribe, but as a "sponsorship", the presiding officer in accordance with the par. 4, part 3 of the Art. 340 of RF Criminal Procedure Code brought this position to the jury and explained a possible option to them to evaluate such actions if they recognize the position of the defendant as justified. But they did not agree with her [3].

5) Explains to the jury the basic rules of evidence evaluation in their totality; the essence of innocence presumption principle; the provision on the interpretation of unresolved doubts in favor of the defendant; the provision that their verdict can be based only on those evidences that are directly studied during the court session, no evidence has a predetermined strength for them, their conclusions can not be based on assumptions, and also on evidence recognized by the court as inadmissible. This requirement contains the basic rules of evidence evaluation obtained and examined during the court session. The presiding judge can not assess personally the truthfulness or the falsity of any evidence in his appeal to the jury.

6) Draws the attention of the jury to the fact that the defendant's refusal to testify or his silence in the court does not have legal significance and can not be interpreted as the evidence of the defendant's guilt. This important rule testifies to the guarantee of the constitutional provision contained in the Art. 51 of RF Constitution, which is supplemented by the prohibition to recognize the defendant as guilty in the absence of evidence other than his confession (Part 2, Article 77 of RF CPC). It should be clear to the jury that the refusal to testify and the provision of false testimonies by the defendant are the forms of his defense that do not conflict with criminal procedural law.

7) Clarifies the order of the jury meeting, the preparation of answers to the posed questions, the voting on the answers and a verdict making. The clarification means the bringing to the jury the meaning and content of the procedure for their forthcoming meeting and the discussion of the issues in the form which is clear for them. So, for example, in the criminal case considered by the jury, the adoption of a unanimous decision on the first issue by the jury about the absence of an offense against G., A. and T. in the presence of the corpse $G$. with the signs of violent death, the conclusions of forensic medical examinations about the presence of knife wounds among $A$. and T., showed that the structure of the issue about the crime was incomprehensible to all jurors, was cumbersome and combined several acts against different persons, which excludes an unequivocal decision by the jury. These circumstances also indicate that the provisions of paragraph 7, Part 3 of the Art. 340 of RF CPC were violated, the presiding judge did 
not explain clearly the procedure to the jury for the preparation of answers to the questions posed. Thus, the acquittal was abolished [1].

The provision of trial participant safety and an effective trial in jury trials is one of the many criminal procedure guarantees. This problem attracts the attention of domestic scientists [2], the judicial practice can be found in separate decisions of the European Court on Human Rights [3].

It seems that the security provision for protected individuals should be considered as one of the actual criminal procedural and also tactical tasks of judicial proceedings, which is a specific set of specific tactical issues identified by the need to take security measures. The tactical task of safety provision for the persons who support investigation should include the appropriate tactical means of its solution in the form of certain tactical methods and complexes and their combination. The implementation of these tactical tools is preceded by the process of making tactical decisions by the court aimed at security provision in respect of the protected persons on the basis of case material careful examination.

The development and the solution of the tactical task ensuring the security of protected individuals should be based on forensic analysis and the court assessment, the judicial review of the judicial situation at a certain point in time, as well as on the tactical forecasting and planning of the necessary tactical mean production. So, in case of a threat to the security of a suspect or an accused with whom a pre-trial cooperation agreement was concluded, the materials of the criminal case, identifying his identity, are withdrawn from the initiated criminal case and attached to the criminal case against the suspect or the accused allocated to a separate proceeding (paragraph 4, Part 2, Article 154 of CPC).

The criminal procedural security measure used in criminal proceedings is the questioning of a witness who has failed to disclose genuine data about a person in the circumstances that exclude his visual observation by other trial participants.

When they provided the testimony of participants in criminal proceedings defended by pseudonyms, various special technical means can be used during judicial examination, excluding audiovisual observation of the protected person by other participants of the trial, the prosecutors and the lawyers. Thus, a videoconference system is used in court practice to prevent the identification of the protected person visually and by voice through the creation of special audio and video jamming. This means of protection creates an obstacle to a protected person location finding and at the same time provides an opportunity for the trial participants to ask him the necessary questions and receive answers.

\section{CONCLUSIONS}

1) The procedure, the content and the form of a parting word provision to the presiding judge, addressed to the jury, requires maximum concentration from the judge to analyze the actual circumstances of the case, the examined evidence, the legal position of the parties set forth in the debate, and the prohibition of preliminary solution of the questions posed by the jury.

2) The development of situationally conditioned forensic recommendations in the direction of an optimal solution of tactical tasks, related to the provision of protected person safety in judicial proceedings, seems promising.

3) The development of typical forensic programs (algorithms) to solve such problems with regard to judicial actions conducted in certain judicial situations is almost justified [1]. 


\section{SUMMARY}

The procedure for making statements by the presiding judge in relation to the jurors on a criminal case during a legal proceeding has a clear legal regulation. A professional judge does not have the right to prejudge the jury conclusions on the one hand. On the other hand, he is obliged to explain as much as possible all the circumstances of the case, established in the court proceedings in compliance with the principle of adversarialism. The application of state protection measures and criminal procedural safety of the trial participants contributes to the objectivity and the completeness of the investigation concerning the criminal case evidence. The use of forensic techniques during the trial is also an important circumstance conducive to a fair verdict provision.

\section{ACKNOWLEDGEMENTS}

The work is performed according to the Russian Government Program of Competitive Growth of Kazan Federal University.

\section{FOOTNOTES}

1. Resolution of RF Supreme Court Plenum No. 23 (Edited on December 22, 2015) "On the application of the norms of RF CPC regulating legal proceedings with the participation of jurors" issued on November 22, 2005 // Rossiyskaya Gazeta. N 272. 02.12.2005.

2. Appeal definition of RF Supreme Court N 59-APU17-12SP issued on December 26, 2017 // The document was not published. SPS Consultant Plus.

3. Vedishchev N.P. The errors, allowed at the parting word by the presiding judge, as the basis for the sentence appeal // Advocate. 2011. N 5. pp. 48 - 56.

4. For more details, see, for example: Yepikhin A.Yu. Preconditions to apply security measures for the trial participants // From the collection: Proceedings of the International Scientific Conference "Tatishchev Readings": Actual Problems of Science and Practice. "Humanities and Education: Experience, Problems, Prospects. Togliatti, 2004. pp. 180-183.

5. Belyaev M.V. On some ways of influencing the procedural information perception by the jurors // The Russian judge. 2017. N 5. pp. 23 - 27.

6. The definition of RF Supreme Court N 78-009-8cn issued on 05.03.2009 // The document was not published. SPS Consultant Plus.

7. Vladykina T. The parting word of the presiding judge // Criminal law. 2011. N 6. pp. 75 - 83.

8. Kanevsky B., Bosov A. The parting word of the presiding judge from the point of view of speech acts // Criminal law. 2013. N 2. pp. 97 - 103.

9. The review of RF Supreme Court judicial practice "The review of Judicial Collegium cassation practice on Criminal Cases of RF Supreme Court in 2004" // Bulletin of RF Supreme Court. 2005. N 8.

10. Kanevsky B., Bosov A. The parting word of the presiding judge from the point of view of speech acts // Criminal law. 2013. N 2. pp. 97 - 103.

11. For more details, see, for example: Aleksandrov A.S., Bosov A.E. Objectivity and impartiality of the parting word (the history of one examination) // The magistrate judge. 2013. N 5. pp. 21-27; Kanevsky B., Bosov A. The parting word of the presiding judge from the point of view of speech acts // Criminal law. 2013. N 2. pp. 97 - 103. 
12. Cassation definition of RF Supreme Court N 35-011-20sp issued on July 21, 2011 // The document was not published. SPS Consultant Plus.

13. Cassation definition of RF Supreme Court N 21-011-15Cח issued on 05.07.2011 // The document was not published. SPS Consultant Plus.

14. Epikhin, A.Y. et al. Protection by the government and security support for the parties of modern criminal process in Russia: Problems and perspectives, Journal of Legal, Ethical and Regulatory Issues Volume 19, Special Issue, 2016; Epikhin, A.Y. et al. Protection of the Witnesses and Victims: International Legal Acts, Legislation of some States and the Modern Russian Legislation. Journal of Advanced Research in Law and Economics, [S.I.], v. 7, n. 2, p. 313-322, may 2016; Epikhin, A.Y. et al. Problem of Definition of Personal Security in the Modern Russian Criminal Procedure. Journal of Advanced Research in Law and Economics, [S.I.], v. 7, n. 6, p. 1539-1545, feb. 2017; Epikhin, A.Y. et al. Protection of the Witnesses and Victims: International Legal Acts, Legislation of some States and the Modern Russian Legislation. Journal of Advanced Research in Law and Economics, [S.I.], v. 7, n. 2, p. 313-322, may 2016.

15. Judgment of the European Court of 26 March 1996 on the merits of the application N 20524/92 Doorson v. the Netherlands. § 70; Judgment of the European Court of 28 March 2002 on the merits of the applications N 47698/99 and 48115/99 Birutis and Others v. Lithuania, § 34, 35; Judgment of the European Court of 28 February 2006 on the merits of the application N 51277/99 Krasniki v. Czech Republic, §64 - 86. Judgment of the European Court of 20 September 1993 on the merits of the application N 14647/89 Saidi v. France, § 44.

16. See: A.Yu. Epikhin, A.V. Mishin. The provision of safety for the persons facilitating criminal justice: Textbook. / A.Yu. Epikhin, A.V. Mishin. -Kazan: Kazan Publishing House. University, 2018. p. 92.

\section{REFERENCES}

Aleksandrov A. S. \& Bosov A. E. (2013). Objectivity and impartiality of the parting word (the history of one examination). The magistrate judge. N 5. 21-27; Kanevsky B., Bosov A. (2013). The parting word of the presiding judge from the point of view of speech acts. Criminal law. N 2. $97-103$.

Appeal definition of RF Supreme Court N 59-APU17-12SP issued on December 26, 2017. The document was not published. SPS Consultant Plus.

Belyaev M. V. (2017). On some ways of influencing the procedural information perception by the jurors. The Russian judge. N 5.23 - 27.

Cassation definition of RF Supreme Court N 21-011-15Cח issued on 05.07.2011. The document was not published. SPS Consultant Plus.

Cassation definition of RF Supreme Court N 35-011-20sp issued on July 21, 2011. The document was not published. SPS Consultant Plus.

Epikhin, A. Y. et al. (2016). Protection by the government and security support for the parties of modern criminal process in Russia: Problems and perspectives. Journal of Legal, Ethical and Regulatory Issues Volume 19, Special Issue.

Epikhin, A. Y. et al. (2016). Protection of the Witnesses and Victims: International Legal Acts, Legislation of some States and the Modern Russian Legislation. Journal of Advanced Research in Law and Economics, [S.I.], v. 7, n. 2. 313-322. 
Epikhin, A. Yu. \& Mishin, A. V. (2018). The provision of safety for the persons facilitating criminal justice: Textbook. Kazan: Kazan Publishing House. University. 92.

Epikhin, A.Y. et al. (2016). Protection of the Witnesses and Victims: International Legal Acts, Legislation of some States and the Modern Russian Legislation. Journal of Advanced Research in Law and Economics, [S.I.], v. 7, n. 2. 313-322.

Epikhin, A.Y. et al. (2017). Problem of Definition of Personal Security in the Modern Russian Criminal Procedure. Journal of Advanced Research in Law and Economics, [S.I.], v. 7, n. 6, 1539-1545.

Judgment of the European Court of 26 March 1996 on the merits of the application N 20524/92 Doorson v. the Netherlands. § 70; Judgment of the European Court of 28 March 2002 on the merits of the applications N 47698/99 and 48115/99 Birutis and Others v. Lithuania, § 34, 35; Judgment of the European Court of 28 February 2006 on the merits of the application N 51277/99 Krasniki v. Czech Republic, § $64-86$. Judgment of the European Court of 20 September 1993 on the merits of the application N 14647/89 Saidi v. France, § 44.

Kanevsky B. \& Bosov A. (2013). The parting word of the presiding judge from the point of view of speech acts. Criminal law. N 2. 97 - 103.

Kanevsky B. \& Bosov A. (2013). The parting word of the presiding judge from the point of view of speech acts. Criminal law. N 2. 97 - 103.

Resolution of RF Supreme Court Plenum No. 23 (Edited on December 22, 2015) "On the application of the norms of RF CPC regulating legal proceedings with the participation of jurors" issued on November 22, 2005. Rossiyskaya Gazeta. N 272.

The definition of RF Supreme Court N 78-009-8cn issued on 05.03.2009. The document was not published. SPS Consultant Plus.

The review of RF Supreme Court judicial practice "The review of Judicial Collegium cassation practice on Criminal Cases of RF Supreme Court in 2004" (2005). Bulletin of RF Supreme Court. N 8.

Vedishchev N. P. (2011). The errors, allowed at the parting word by the presiding judge, as the basis for the sentence appeal. Advocate. N 5. 48 - 56.

Vladykina T. (2011). The parting word of the presiding judge. Criminal law. N 6. 75 - 83.

Yepikhin A. Yu. (2004). Preconditions to apply security measures for the trial participants. From the collection: Proceedings of the International Scientific Conference "Tatishchev Readings": Actual Problems of Science and Practice. "Humanities and Education: Experience, Problems, Prospects. Togliatti. 180-183. 